\title{
Export Function Estimates for the Pakistan Carpet Industry
}

\author{
SAM CAMERON and KHAIR-UZ-ZAMAN
}

\section{INTRODUCTION}

This paper explores the behaviour of exports of 'exotic' carpets/rugs from Pakistan over the period from 1970-2003. These rugs are sold purely for decorative purposes mainly to the major Western economies. This sector of world trade has been neglected by economists as there is only one study of Iranian carpet trade [Karimi (2003)] which has so far only been presented as a short abstract.

In this paper we review the historic background to the carpet making industry in Pakistan and look at its current conditions of production. We then go on to estimate an error correction model using conventional trade-related explanatory variables which include the volatility of exchange rates which has been increasingly a focus of such research. The results are broadly supportive of the existing aggregate and disaggregate literature for other countries. Given that the dominant rival supplier-Iran was subjected to constant and varying trade volume rationing activities by the USA, we then attempt to take this into account using measures of Iranian trade disadvantage. These results show that the problems faced by Iranian exporters have had a statistically significant positive impact on the Pakistan carpet export supply function.

\section{BACKGROUND TO CARPET PRODUCTION}

The carpet industry plays a vital role in the economy of Pakistan. It is not only a major earner of foreign exchange for the economy as a whole but it also contributes to the relief of poverty in rural areas. It is basically a cottage industry spread all over Pakistan, especially in remote rural areas. It is a major source of income for families who have few other sources of livelihood, apart from marginal agriculture. Families can easily enter carpet-making as an occupation as it requires few infrastructural facilities. Unlike other industries it does not require electricity, water, etc. A wooden loom, yarn and knotting skill are needed to make carpets. Another advantage for the rural families is that they can do the work inside their homes. Because the work takes place inside homes, female members of the family can also participate in this economic activity. The carpet industry is totally indigenous as even the machines used are manufactured locally.

Ornamental (rugs) carpets have from the beginning been a part of the Islamic culture as it achieved unprecedented heights in Baghdad, Damascus, Cordova, Delhi and in the fabled cities of Central Asia. References to carpets in Arabic and Persian literature are numerous. Wherever Muslim culture has flourished, carpet weaving has been prominent.

Sam Cameron<samcameron@lineone.net> is associated with Bradford Centre for International Development, Bradford University, UK. Khair-uz-Zaman <drkzaman2001@yahoo.com> is associated with the Department of Economics, Gomal University, D. I. Khan. 
Historians believe that carpet making was introduced to the region now constituting Pakistan as far back as the 11th century with the coming of the first Muslim conquerors the Ghaznavids and the Ghauris. During the Mughal period the carpets made in the Indo-Pak Sub-Continent became so famous that there was mounting demand for them abroad. These carpets have distinctive designs and boasted a rich knotting density. After the partition of the Sub-Continent in 1947 to establish the new Muslim State of Pakistan, most of the Muslims migrating to Pakistan, settled down either in Lahore or in Karachi. It is these people who formed the backbone of the carpet industry. The type of carpet used is not mass-market domestic floor covering but is more appropriately characterised as part of the exotic 'rug' trade. The rugs are individually made from a process of knotting with a unique pattern rather than mass-produced. In the world market such rugs are best known as 'Persian' rugs and Turkish rugs although Iran and Turkey are not the sole suppliers. According to the Pakistan Carpet Manufacturers and Exporters Association [PCMEA (2003)] there are 150000-200000 looms in the country. The number of weavers is estimated around 200000-250000. Carpet making takes place in all the four provinces of Pakistan.

\section{Salient Features of Carpet Industry}

- It provides jobs to 1.5 million people in the country (2003).

- It earns $\$ 300$ million foreign exchange annually (2003).

- More than 99 percent of carpets made in the country are exported. Local consumption is negligible (2003).

- Average share in total exports is 2.48 percent [Rozina (2004)].

- There are six leading carpet suppliers in the world market i.e.; Iran, Pakistan, India, China, Nepal and Turkey.

- Carpet-making tends to be dependent on child labour in Nepal, Iran, Turkey, Pakistan and India [ILO (2003)].

- Iranian and Pakistani hand-made carpets dominate the USA market. The German market for silk carpet is dominated by India and China. The south-East Asian market is dominated by China and Pakistan [Export Promotion Bureau (2003)].

Data on exports of carpet for the period 1994-95 to 2001-2002 are shown in Table 1 which also shows the export share.

Table 1

Pakistan Carpet Exports (Value) 1994-5-2002-3

\begin{tabular}{lcc}
\hline Year & Exports (Million \$) & Share in Total Exports \\
\hline $1994-95$ & 195.4 & 2.4 \\
$1995-96$ & 205.3 & 2.4 \\
$1996-97$ & 195.9 & 2.5 \\
$1997-98$ & 197.4 & 2.3 \\
$1998-99$ & 202.7 & 2.6 \\
$1999-2000$ & 250.0 & 3.0 \\
$2000-20001$ & 288.0 & 3.3 \\
$2001-2002$ & 249.6 & 3.4 \\
\hline Source: Pakistan and Gulf Economists (2004). & &
\end{tabular}

Source: Pakistan and Gulf Economists (2004). 
Table 2 Shows the Pattern of Buying Behaviour for Pakistan's Carpet Exports.

Table 2

Top 10 Buyers of Pakistani Carpet

\begin{tabular}{clcccc}
\hline & & \multicolumn{4}{c}{ Value in 000 \$ } \\
\cline { 2 - 5 } S.No. & Top 10 Buyer Countries & $2002-2003$ & \% Share & $2001-2002$ & $\%$ Share \\
\hline 1 & U S A & 89,740 & 40.63 & 5,640 & 38.32 \\
2 & Germany & 22,688 & 10.27 & 31,230 & 12.51 \\
3 & Italy & 19,974 & 9.04 & 13,996 & 5.61 \\
4 & United Kingdom & 12,181 & 5.51 & 15,753 & 6.31 \\
5 & France & 9,937 & 4.50 & 12,588 & 5.04 \\
6 & UAE & 8,389 & 3.80 & 9,835 & 3.94 \\
7 & Japan & 7,497 & 3.39 & 6,965 & 2.79 \\
8 & Canada & 7,188 & 3.25 & 6,183 & 2.48 \\
9 & Spain & 5,128 & 2.32 & 4,584 & 1.84 \\
10 & Greece & 5,052 & 2.29 & 2,740 & 1.10 \\
& Sub-total & 187,774 & 85.01 & 199,514 & 79.94 \\
11 & Turkey & 3,736 & 1.69 & 9,592 & 3.84 \\
12 & Saudi Arabia & 2,845 & 1.29 & 4,806 & 1.93 \\
13 & Switzerland & 2,800 & 1.27 & 6,338 & 2.54 \\
14 & South Africa & 2,741 & 1.24 & 3,460 & 1.39 \\
15 & Australia & 2,685 & 1.22 & 3,697 & 1.48 \\
16 & Sweden & 1,831 & 0.83 & 2,599 & 1.04 \\
17 & Denmark & 1,712 & 0.78 & 1,447 & 0.58 \\
18 & Singapore & 1,321 & 0.60 & 2,719 & 1.09 \\
19 & Lebanon & 1,298 & 0.59 & 1,213 & 0.49 \\
20 & Belgium & 1,051 & 0.48 & 2,040 & 0.82 \\
& Sub- total & 22,020 & 9.97 & 37,911 & 15.19 \\
& Sub- total of 20 Countries & 209,794 & 94.98 & 237,425 & 95.13 \\
& Others & 11,105 & 5.03 & 12,149 & 4.87 \\
& Total & 220,899 & 100.00 & 249,574 & 100.00 \\
\hline Source: Export Promotion Bureau (2003). & & & & \\
& & & & &
\end{tabular}

In 2003, Pakistan retains its second position with a market share of 28.37 percent and export \$12 million to United States. Other suppliers include, Iran with market share of 35.5 percent (export to U.S \$ 13.6), India with a market share of 7.6 percent (export to U.S \$ 2.9 million), Nepal with a market share of 3.4 percent (export to U.S \$ 1.3 million), China with a market share of 3.2 percent (export to U.S \$ 3.2 million), Turkey with a market share of 1.8 percent (export to U.S \$ 0.7 million) and Russia with a market share 0.02 percent [Export Promotion Bureau (2003)].

\section{EXPORT MODELS}

There have been a huge number of empirical studies of export functions [see e.g. Arize (1999), Bahmani, et al. (1992), Smith (1999)], generally based on the notion of specialised profit-maximising firms. This literature has included the obvious price and scale measures (GDP in the supplying nation, exchange rate and unit price measures) but has more recently brought in the additional factor of exchange rate volatility [De Grauwe (1988), Thursby and Thursby (1987), Pozo (1992), McKenzie (1999)]. There is an obvious policy interest in this variable, as a finding of a negative coefficient would 
suggest that policies to stabilise exchange rates would bring gains in trade volume even if there is no direct relationship between trade and the level of exchange rates.

However, there is no consistency in the literature, theoretical or empirical on the effects of exchange rate variability on export trade. Several models have been proposed suggesting that exchange rate variability might adversely affect trade. [Barkoulas, Baum and Caglayan (2002); De Grauwe (1988)]. Conversely, the literature also offers several reasons why exchange rate variability might benefit export trade. As exports contracts are usually denominated in foreign currency, exchange rate variability induces uncertainty in the pricing decisions of domestic firms engaged in export business [Abbott, et al. (2001) and Arize (1997)].

Most of this research is aggregated at national level or disaggregated to industry level often still at high levels of aggregation. The empirical work has found a variety of null, positive and negative effects of volatility but generally where the effects are significant, they have tended to be negative.

So far as the exports of ornamental exotic rugs is concerned, there is no empirical work except Karimi (2003), who has estimated export supply function for Iran using carpet and pistachio sectors over 1970-1998. His export supply function is given in the following form:

$$
\begin{aligned}
\log X s & =b 0+b 1 \log (P x /(P b \cdot E r))+b 2 \log (X-1) /(P b-1 . E r)+b 3 \log Y R \\
& +b 4 \log S S R+b 5 T .
\end{aligned}
$$

where $X s=$ real export volume, $P b=$ domestic price in national currency, $P x=$ export price, $E R=$ exchange rate in producer country in dollar, $Y R=$ produce of selective output in the country, $S S R=$ supply side shock and $T=$ time trend.

Given that the abstract is the only source for this paper we cannot be more precise on the details. He concludes that the price elasticities of export supply of carpet and pistachio are high and that the exchange rate has a positive and direct effect for both products. It should be noted that Karimi does not include any measures of exchange rate volatility therefore his estimates may be biased if this is an important omitted variable. Also, we have so far only seen the abstract of the paper we have not seen the actual estimated results.

In this paper we follow the concepts and measurement, which are accepted in the literature, on exchange rate volatility, leading to an equation of the form:

$$
\log X_{t}=a_{0}+a_{1} \log Y_{t}+a_{2} \log P R_{t}+a_{3} \log E R_{t}+a_{4} \log E V_{t}+u_{t}
$$

where

$$
\begin{aligned}
X t & =\text { Real carpet exports (volume) } \\
Y t & =\text { Real GDP (Pakistan) } \\
P R t & =\text { Relative prices i.e. export price/domestic price } \\
E R & =\text { Exchange rate } \\
V t & =\text { Exchange rate volatility }
\end{aligned}
$$

We have used the measure of exchange rate volatility, typically used in the literature, based on the moving standard deviation of the exchange rate (i.e. standard deviation of 4-year moving average of exchange rate). All the variables are in real terms. 


\section{Data Sources}

Annual data is used for the period of 1970-2003. The data is taken from International Financial Statistics and Pakistan Economic Survey.

\section{ESTIMATION AND RESULTS}

Given that this is annual time-series data, we need to pre-test the data for stationarity and the existence of a cointegration vector before we move on the specification of an error-correction model

\section{(i) Unit Root and Cointegration Tests}

The first step in the estimation is to determine the order of integration of variables under consideration. The unit root test employed for testing the order of integration is augmented Dickey-Fuller test. The test statistics rejects the null hypothesis of non-stationarity of all variables, when first difference variables are used. Thus indicating variables are stationary of order 1, i.e., 1 (1).

Table 3

Results of Unit Root Test

\begin{tabular}{|c|c|c|c|c|c|}
\hline \multirow[b]{2}{*}{ Variables } & \multicolumn{2}{|c|}{ ADF in Levels } & \multicolumn{2}{|c|}{ ADF in First Differences } & \multirow[b]{2}{*}{$\mathrm{I}(\mathrm{)}$} \\
\hline & Without Trend & With Trend & Without Trend & with Trend & \\
\hline $\mathrm{Xt}$ & -2.13 & -2.32 & -5.60 & -5.72 & $\mathrm{I}(1)$ \\
\hline Yt & -1.35 & -0.25 & -5.61 & -6.48 & $\mathrm{I}(1)$ \\
\hline PRt & -8.18 & -7.71 & -5.48 & -5.14 & $\mathrm{I}(0)$ \\
\hline ERt & -1.37 & -3.54 & -14.44 & -14.94 & $\mathrm{I}(1)$ \\
\hline $\mathrm{EVt}$ & -1.55 & -2.48 & -4.41 & -4.32 & $\mathrm{I}(1)$ \\
\hline $\begin{array}{ll}\text { ote: } & \text { All v } \\
& \text { Criti } \\
& \text { Criti }\end{array}$ & $\begin{array}{l}\text { are me } \\
\text { at } 5 \\
\text { at } 5\end{array}$ & $\begin{array}{l}\text { tural logar } \\
.95 \text { (with } \\
.55 \text { (with }\end{array}$ & 1); and & & \\
\hline
\end{tabular}

\section{(ii) Testing for Cointegration}

A number of methods of testing for co-integration have been proposed in the literature. We use Engle-Granger (EG) or AEG test:

We first get our co-integrating regression:

$$
\begin{array}{ccccc}
\hat{L} X t)= & -16.76 & 2.65(L Y t)+1.14(L P R t) & -1.37(L E t) & -0.19(L V t) \\
(-5.04) & (6.07) & (3.76) & (-4.85)
\end{array}
$$

$R^{2}=0.82$

D. $\mathrm{W}=0.99$

Note: $t$-ratios are in parenthesis. 
Then we performed a unit root test on the residuals $(\delta \mathrm{t})$ obtain from the above estimation, we obtain the following results:

$\mathrm{ADF}$ of $\mathrm{Rz}=-3.05$, while $\mathrm{E} . \mathrm{G}$ at 5 percent $=-2.96$.

Since the computed ' $t$ ' value is much larger in absolute terms, our conclusion is that the residuals from the regression are $\mathrm{I}(0)$; i.e. they are stationary. One can call the estimated equation the static or long run relationship function and interpret its parameter as long run parameters.

\section{(iii) Error Correction Model (Mechanism) ECM}

Although there is an apparent long-run equilibrium relationship but in the shortrun there may be disequilibrium. Therefore, one can treat the error term as the equilibrium error. We can use this error term to tie the short-run behaviour of carpet export supply to its long run values. The ECM first used by Sargan (1984) and later popularized by Engle and Granger was estimated as follows:

$$
\hat{d} L X t=0.01+1.97 d L Y t+0.55 d L P R t-0.70 d L E R t-0.02 d L V t-0.40 \delta t-1
$$

$$
\begin{array}{lllll}
(0.11) & (1.21) \quad(2.09) \quad(-2.81) \quad(-0.33) \quad(-2.89)
\end{array}
$$

$\mathrm{R}^{2}=0.39 \quad$ D.W $=1.67$

( $t$-ratios in brackets and $d$ is first difference).

This is a fairly satisfactory equation which has an adjustment coefficient in the middle of the range which is statistically significant. The coefficient on the scale factor $(d L Y)$ suggests that there is no relationship between the growth of rug exports and overall Pakistan output in this period. The 'price' factors (relative unit prices and exchange rates) have the expected sign and are statistically significant at reasonable levels. Exchange rate volatility appears to have no impact on the volume of trade.

\section{A RECONSIDERATION OF THE EXPORT FUNCTION}

The previous section has estimated a fairly conventional exchange rate volatility augmented export function. So far we have ignored the presence of external shocks on the market for exotic rugs. As can be seen from the descriptive statistics, in section two, the major competitor in this market is Iran which benefits from a long traditional reputation in the production of rugs. During a substantial amount of the period under consideration, Iranian exports were subject to a series of attempts to curtail them by American politicians [see Pesaran (1988)].

Such factors raise problems of possible bias and instability in the work we have reported so far. One response to this would be to simply include a dummy variable to proxy the presence of politically motivated trade barriers. We would expect this to have a positive coefficient assuming that Pakistani rugs are not imperfect substitutes for Iranian rugs and that the transactions costs of cover evasion are not neglible. The problem with such a dummy variable is that there is great variability over time in the scope and level of enforcement of politically motivated trade restrictions. 
Askari, et al. (2001) tabulates the various stages of US trade blockages against Iranian exporters in general. He goes on to estimate how much trade dislocation, in total is due to the measures taken. This is reported in Table 4 below.

Table 4

Estimated Reduction in Direct U.S._- Iran Merchandise Trade as a Result of Sanctions (in Billions of Dollars)

\begin{tabular}{|c|c|c|}
\hline Year & $\begin{array}{c}\text { Askari } \text { et al. Estimated } \\
\text { Reduction in U.S. Exports to } \\
\text { Iran }\end{array}$ & $\begin{array}{c}\text { Askari } \text { et al. Estimated } \\
\text { Reduction in U.S. Imports } \\
\text { from Iran } \\
\end{array}$ \\
\hline 1980 & 1.5 & 0.8 \\
\hline 1981 & 1.5 & 1.4 \\
\hline 1982 & 1.9 & 1.1 \\
\hline 1983 & 2.1 & 1.2 \\
\hline 1984 & 2.3 & 2.4 \\
\hline 1985 & 2.4 & 2.3 \\
\hline 1986 & 2.2 & 2.8 \\
\hline 1987 & 1.4 & 0.7 \\
\hline 1988 & 1.3 & 1.6 \\
\hline 1989 & 1.3 & 1.7 \\
\hline 1990 & 1.2 & 1.6 \\
\hline 1991 & 1.2 & 1.7 \\
\hline 1992 & 0.7 & 1.6 \\
\hline 1993 & 0.3 & 0.8 \\
\hline 1994 & 0.5 & 0.8 \\
\hline 1995 & 0.6 & 0.9 \\
\hline 1996 & 1.0 & 1.3 \\
\hline 1997 & 1.3 & 1.5 \\
\hline 1998 & 1.4 & 2.0 \\
\hline
\end{tabular}

The disruptions to trade may have undermined the stability of the export function. One approach to this is to conduct stability tests on the regression. In view of the above, we first take the strategy of simply checking the stability of the model using CUSUM tests in an attempt to find the time point at which any notable structural break occurs. These are shown in figures. 
Fig. 1. 1970-2003. Plot of Cumulative Sum of Recursive Residuals

Plot of Cumulative Sum of Squares of Recursive Residuals

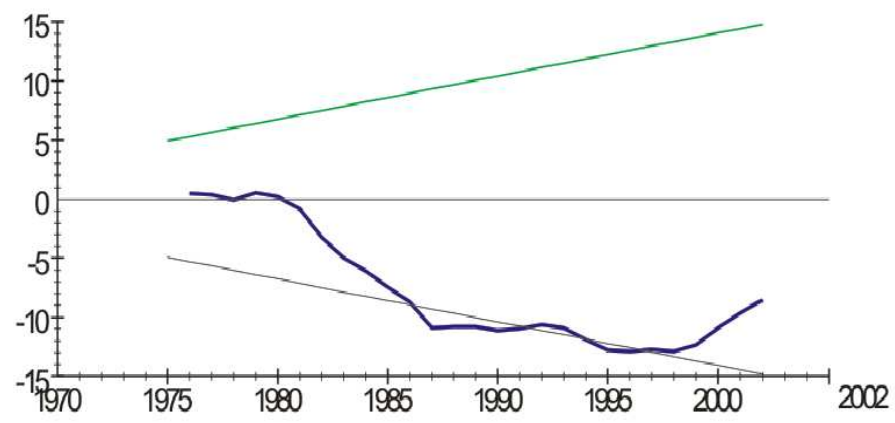

The Straight Lines Represent Official Bounds at 5 Percent Significance Level

Fig. 2. 1970-2003. Plot of Cumulative Sum of Squares of Recursive Residuals

Plot of Cumulative Sum of Squares of Recursive Residuals

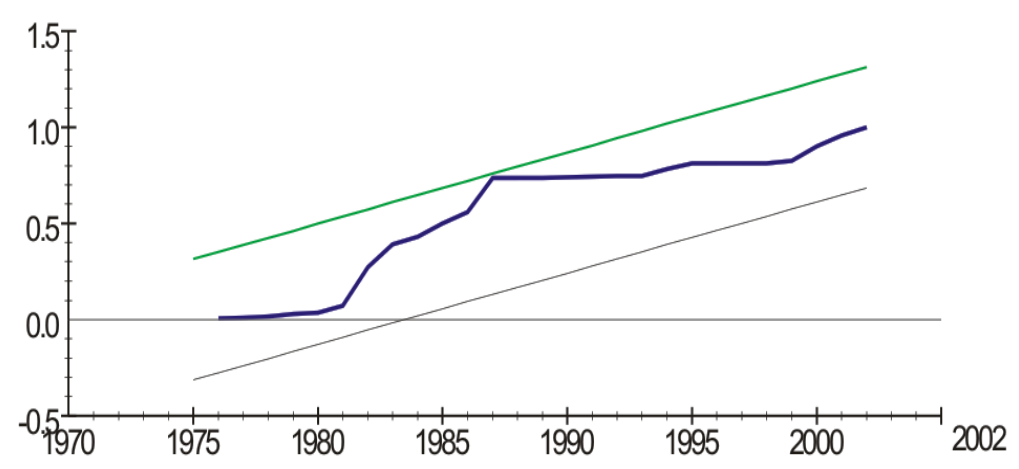

The Straight Lines Represent Official Bounds at 5 Percent Significance Level

These graphs suggest some tendency of the relationship to shift around 1985. A more satisfactory method of dealing with the Iranian trade embargo factor in Pakistani carpet exports would be to find some scalar index of the degree to which the various sanction 'bite' at a given point in time. For this purpose we use the measure of trade loss presented by Askari (2001), to augment the ECM (see Table 4). Unfortunately this limits us to the time period 1980-1998. To facilitate a proper comparison with the equation used earlier we present a re-estimation of it over this period alongside the same equation with the Iran variable added. Results are as follows:

1980-1998 (including Iran Variable)

$\hat{d} L X t=-0.001+0.09 d L Y t-0.67 d L P R t-0.59 d L E R t+0.60 d L V t+0.31 d L I r a n-0.95 \delta t-1$
$(-0.01)(0.05) \quad(-1.21) \quad(-1.12) \quad(1.96)$

$\mathrm{R}^{2}=0.85 \quad$ D. $\mathrm{W}=1.31$

( $t$-ratios in brackets and $d$ is first difference). 
1980-1998 (without Iran Variable)

$$
\begin{aligned}
& \hat{d} L X t=-0.01+0.67 d L Y t-0.51 d L P R t-0.52 d L E R t+0.34 d L V t-0.96 \delta t-1 \\
& \begin{array}{lllll}
(-0.09) & (0.25) & (-0.61) & (-0.60) & (0.71)
\end{array}
\end{aligned}
$$

The inclusion of the Iran trade blockage variable has a dramatic impact on the estimated equation. The Iran variable itself is highly statistically significant with the expected positive sign and a short-run point elasticity of (0.31). Its inclusion pushes the $t$ ratio on the volatility measure up considerably to (1.96) and generates a fairly large positive coefficient suggesting that exchange rate volatility increases Pakistan carpet exports but only when the effect of Iranian trade disruptions is controlled for.

We should of course be cautious with the use of such a short time-period. The truncation of the sample to 1980-1998 has some notable effects other than on exchange rate volatility. None of the three 'core' trade variables-relative prices, exchange rates and domestic output are statistically significant. In addition there seem to be problems with the ECM model as the Durbin-Watson statistics have drifted further away from 2 and the adjustment coefficient has drifted towards the edge of the unit interval.

\section{SUMMARY AND CONCLUSION}

This paper has provided the first estimates of export supply functions for the Pakistan carpet sector. This is an important source of export revenue for the host economy. We have focused on the traditional export supply factors of relative prices/exchange rates and have also looked at the additional influence of exchange rate volatility on the supply of carpet exports. The expected results were found for aggregate relative prices. The speed of adjustment towards long-run equilibrium in the error correction model is in the middle of the range which is statistically significant. It also suggests that the overall output of Pakistan have no impact on the export of carpet. However, the rest of the variables such as relative prices and exchange rates have the expected signs and are statistically significant at reasonable levels.

We re-estimated the export function including Iran variable and the results are given in the above mentioned table. The inclusion of Iran variable has a dramatic impact on the estimated equation. The Iran variable as well as the exchange rate volatility variable are statistically significant while the rest of the variables are statistically not significant. It is notable that the exchange rate volatility now has a positive effect which is a finding that is less common in the literature although one which is not anomalous.

There is an obvious conclusion one could draw from this work. That is, the politically hostile trade environment towards Iran has been of considerable benefit to Pakistan, particularly in rural areas, via the gain in trade to the indigenous rug industry.

\section{REFERENCES}

Abbott, A., A. C. Darnell, and L. Evans (2001) The Influence of Exchange Rate Variability on UK Exports. Applied Economic Letters 8, 47-49. 
Arize, A. C. (1997) Foreign Trade and Exchange Rate Risk in the G-7 Countries: Cointegration and Error-correction Models. Review of Financial Economics 6:1, 95112.

Arize, A.C. (1999) The Demand for LDC Exports: Estimates from Singapore. The International Trade Journal 13:4, 345-370.

Askari, H., F. John, T. Hildy, and F. Jiawen (2001) U.S. Economic Sanctions: Lessons from the Iranian Experience. Business Economics 76:3.

Bahmani-Oskooee, M. and N. Ltaifa (1992) Effects of Exchange Rate Risk on Exports: Cross Country Analysis. World Development 20:8, 1173-1181.

Barkoulas, J. T., C. F. Baum and M. Caglayan (2002) Exchange Rate Effects on the Volume and Variability of Trade Flows. Journal of International Money and Finance 21:4, 481-496.

De Grauwe, P. (1988) Exchange Rate Variability and the Slowdown in Growth of International Trade. IMF Staff Papers 35, 63-84.

Karimi, M. S. (2003). Non-oil Export Supply Model in Iran (Carpet, Pistachio). Abstract of Paper Submitted to European Regional Science Association (ERSA), University of Jyvaskyla, Finland.

McKkenzie, M. D. (1999) The Impact of Exchange Rate Volatility on International Trade Flows. Journal of Economic Survey 13:1, 71-106.

Pakistan, Government of (2003) Export Promotion Bureau, Islamabad.

Pesaran, M. H. (1998) Economic Trends and Macroeconomic Policies in Post Revolution Iran. Department of Applied Economics, University of Cambridge. (Cambridge Working Papers in Economics, 9818.)

Pozo, S. (1992) Conditional Exchange Rate Volatility and the Volume of International Trade: Evidence from the Early 1900s. Review of Economics and Statistics 74, 325329.

Rozina Shaheen (2004) Carpet Industry in Pakistan. Pakistan and Gulf Economists Issue 32.

Smith, C. E. (1999) Exchange Rate Variation, Commodity Price Variation and the Implications for International Trade. Journal of International Money and Finance 18:3, 471-491.

Thursby, J. G. and M. C. Thursby (1987) Bilateral Trade Flows, the Linder Hypothesis, and Exchange Risk. Review of Economics and Statistics 69:3, 488-495. 


\section{Comments}

The paper explores the behaviour of export of exotic carpet rugs from Pakistan over the period 1970-03, using a simple error correction model. The paper accounts for the fact that main rival Iran was disadvantaged in the sense that exports from the country were subjected varying degree of rationing by the main importer-United States. To estimate the export function of exotic carpets for Pakistan the paper besides focusing on traditional variables viz. relative prices and exchange rate also investigates the influence of exchange rate volatility on exports. The authors find that the rationing of imports from Iran had positive impact upon exports of carpets from Pakistan. Moreover the study finds that exchange rate volatility also casts a positive influence on exports when the export function is estimated accounting for impact of sanctions on Iran.

The authors deserve appreciation for presenting a technically sound paper and venturing into a relatively unexplored area. Besides, the inclusion of the exchange rate volatility in the export function is also commendable. However, given the smaller share of carpet exports in total exports, one should exhibit caution in drawing policy implication from the finding regarding the impact of exchange rate volatility on carpet exports.

\section{Idrees Khawaja}

Pakistan Institute of Development Economics, Islamabad. 